\title{
Public Expectations from Political Office Holders on Good Governance in Oyo State, Nigeria
}

\author{
M. Kolawole Aliyu ${ }^{1}$, Hope Amoge Ikedinma ${ }^{1}$, Nwaugha Livinus ${ }^{1} \&$ Salaam Rasak Olanrewaju ${ }^{1}$ \\ ${ }^{1}$ Department of Political Science, Obafemi Awolowo University, Ile-Ife, Nigeria \\ Correspondence: M. Kolawole Aliyu, Department of Political Science, Obafemi Awolowo University, Ile-Ife, \\ Nigeria. E-mail: aliyukolawole2014@yahoo.com
}

Received: May 29, 2019

doi:10.5539/jpl.v12n3p136
Accepted: June 27, 2019 Online Published: August 30, 2019

URL: https://doi.org/10.5539/jpl.v12n3p136

\begin{abstract}
This study examines the expectations of the electorates from political office holders, using Oyo state as a case study. It also finds out how feasible the expectations are, and if political office holders are able to meet such expectations. The study equally examines the factors that aid and prevent such expectations from being met and discusses the impact of the expectations on good governance in the study area. Primary data was sourced with a self structured questionnaire administered on 150 respondents drawn from electorates, public officials/elected officials and civil society organizations across the 33 local government areas of Oyo State, analyzed by Statistical Package for Social Scientist (SPSS) and interpreted in percentages and frequency distribution. The secondary data was sourced from books, journals, newspapers publications and internet materials, and content analyzed. The study revealed that people have varied expectations but same on medical facilities, poverty alleviation, security of lives and property, education and economic development. The study also revealed that political office holders are aware of the expectations of the people through the mass media, social media and direct contact but do not meet them. The study found that adequate fund and manpower are key factors that help political office holders to meet up with the expectations and that lack of funds; inadequate manpower, corruption, and influence of political godfathers are hindrances to meeting up with the expectations of the electorates. It also found that public expectations have impact on good governance and that the impact is a positive one.
\end{abstract}

Keywords: electorates, expectations, political office holders, governance

\section{Introduction}

Good governance is felt on the extent to which the expectations of the electorates are met by elected/appointed political office holders. Thus, the electorates expect public officials to meet up with certain expectations which are considered essential to their well being. Most times, the expectations range from the provision of food, clothing, shelter, employment, social infrastructure, economic development, medical facilities, agriculture, education, industrial development to security of lives and properties. Unfortunately, the expectations are not often met. According to Anyadike and Emeh (2014), most public office holders loot public treasury and could not be said to be serving the public. For example, the list of looters released by the federal government in March 2018 contained names of prominent public office holders (elected and appointed) who had once served the country (Sahara Reporters, 2018).

Public office holders are expected to carry out some important duties but despite the knowledge of things expected of them they still lag behind. The expectations are not cumbersome but basic things that Nigerians yearn for day-in-day-out. For instance, expectations of people on issues such as electricity, good roads, and health care delivery have not been satisfactorily provided, although some of the elected officials have achieved some feats in this regard (Lamidi and Adeyeye, 2013). It has been documented in literature that corruption, absence of cooperation from the citizens, inadequate resources, illiteracy, inadequate personnel, technical know-how, and absence of the merit system account for the inability of the public officials to meet up the expectations (Oaikhena and Osawe, 2012).

The expectations of people are not rigid; once a need is met another one arises because human need is insatiable. A good government is expected to work towards meeting the needs of its citizens but the reverse is the case in Nigerian as there have been cases of negligence of duties on the part of some public officials (Onichakwe, 2016). There have been cases of some political actors falling short in meeting up people's needs in areas of service 
delivery as a result of incompetence. There have also been cases of corrupt leaders who are mainly driven by monetary values (Oaikhena and Osawe, 2016). The corrupt leaders squander public resources at their disposal by putting their interest above the interest of the people (Adenuga, 2013). Some leaders also engage in looting of the public treasury for their own personal needs (Lawal and Dare, 2012). For example, James Ibori was accused of looting public funds to the tune of $\$ 250$ million and jailed for thirteen years by a London judge (Premium Times, 2012; Sahara Reporters, 2018).

Government expenditures are supposed to be informed by the needs of the people (United Nations, 2018). The peoples' need suppose to guide government in its developmental plans. It indirectly helps the people to have a say in the governing process. When public office holders are aware of what the people want, it is easy for them to cater for such needs (Pierre and Ismail, 1991). Unfortunately, this is not always the case because political office holders do not consider the people's opinion in the course of governance as they govern, most time; based on what they feel the people want (Michael, 2004).

\section{Methodology}

This study is a descriptive research and focused Oyo state during the administration of former Governor Isiak Abiola Ajimobi from 2011 to 2018. Oyo state is purposively chosen, especially the administration of Governor Abiola Ajimobi, being a two-term governor in the state since $29^{\text {th }}$ May, 1999 when democratic rule returned to Nigeria. The study made use of primary and secondary data. The primary data was sourced with a self structured questionnaire administered on 150 respondents drawn from electorates, public officials and civil society organizations across the 33 local government areas of Oyo State. The local governments include Afijio, Akinyele, Atiba, Atisbo, Egbeda, Ibadan North, Ibadan North East, Ibadan North West, Ibadan South East, Ibadan South West, Ibadan Central, Ibarapa East, Ibarapa North, Ido, Irepo, Iseyin, Itesiwaju, Iwajowa, Kajola, Lagelu, Ogo-Oluwa, Ogbomoso North, Ogbomoso South, Olorunsogo, Oluloye, Oorelope, Ona-Ara, Orire, Oyo East, Oyo West, Saki East, Saki West and Surulere. Simple random sampling technique was adopted to pick respondents. The primary data was analyzed by using Statistical Package for Social Scientist (SPSS) and interpreted in percentages, frequency distribution and cross tabulations. The secondary data was sourced from books, journals, newspapers publications and internet materials, and content analyzed.

\subsection{Research Questions}

This study seeks to provide answers to the following questions:

(i) What are the expectations of the people from political office holders?

(ii) How feasible are the expectations of the electorates?

(iii) Have political office holders effectively met the expectations of the electorates?

(iv) What are the factors that inhibit and enhance political office holder in meeting the expectations of the electorates?

(v) What impact do public expectations have on good governance?

\subsection{Research Objectives}

The objectives of the study are to:

(i) examine what constitute expectations of the electorate on public office holders

(ii) find out how feasible the expectations are

(iii) find out if political office holders have been able to effectively meet public expectations in the study area

(iv) examine the factors that inhibit and enhance people's expectations on public office holders

(v) discuss the impact of public expectations on good governance

\subsection{Research Assumptions}

The study is guided by the following assumptions:

(i) Public expectation determines the performance of public office holders

(ii) Expectations from public office holders influence good governance.

\subsection{Conceptual and Empirical Review}

Governance and good governance have no universal definitions. According to Geta (2001), governance is the process of decision making and the process by which decisions are implemented or not implemented. According 
to United Nations (2018), governance consists of 'the manner in which power is exercised in the management of a country's economic and social resources for development. Thus, governance in any society aims to ensure transparency through the exercise of economic, political and administrative authority. Primarily, the emphasis is on 'how political power is exercised to manage a nation's affairs'. Michael (2004) sees governance as the use of power in the management of a country's economic and social resources for development. Governance is all encompassing and this is why Ibeogu and Nkwede (2016)views it as consisting of a complex arrays of processes, organizations and institutions that act as channels for citizens to exercise their legal rights, attempt to resolve differences and fulfill their obligations to the society.

In a related way, good governance is the management of a country's resources and affairs in a manner that is open, transparent, accountable, equitable and responsive to people's needs (Lawal and Dare, 2012). Onichakwe (2016) defines good governance as a process of encouraging "staff incentives, training of civil servants, administrative and fiscal decentralization and dialogue between governments and civil society. In more specific terms, good governance may be defined as the exercise of power in a variety of institutional contexts, the focus of which is to direct, control, and regulate activities in the interests of people, voters and workers. Hence, it can be said that good governance fosters human development through popular participation, social and economic equalities. For good governance to be meaningful there is need for political freedom, constitutional and judicial protection of individual rights, a stable currency, provision of education and health care for all, and the executive's accountability to a freely-elected legislature. In other words, good governance strives to establish quality relationship between the rulers and the ruled (United Nations, 2018). Essentially, Oaikhena and Osawe (2012) provide some parameters for measuring good governance such as transparency in decision-making, accountability in public spending, rule of law, equity, justice and public participation in policy choices.

\subsection{Public Expectations from Political Office Holders in Nigeria: An Analysis}

One major expectation of the public from the government is the security of lives and properties. Security of lives and properties is the pillar upon which other needs rest. Sadly, government has failed to secure the lives of its citizens. Nigeria has been witnessing different security challenges in the northern, eastern and western parts of the country. According to Bada (2018), the activities of the Fulani herdsmen and Boko Haram are a huge problem to the security operatives in the northern parts of Nigeria. Kidnapping and ritual killings are paramount in the eastern and western parts of the country respectively (Okogha, 2018).

The public also expect the government to make policies that would bring development to the country. Despite the fact that government had made plans and policies that would achieve this end, there exist so many policies which were not followed to their ends because of government inconsistency (Anyadike and Emeh, 2014). Most politicians are more concerned in getting re-elected rather than enforcing feasible policies that are needed. In Nigerian politics, a change in government means an end to the old government policies as the new government often times do not complete the project of previous administration but prefer to start new projects (Adamolekun, 2002). Other factors responsible for policy inconsistency are institutional weakness, poor monitoring, inadequate follow ups and poor sequencing, low skilled manpower, party politics, unhealthy inter-ministerial rivalry, and absence of commitment and political will to implement policies. Another factor to be considered which affects public expectations on good governance is corruption. As pointed out by Sahara Reporters (2018), public office holders who were appointed or elected to govern have been found wanting of embezzling public funds. According to the list of looters released by the federal government in March 2018, prominent and influential Nigerians dominate the list (Sahara Reporters, 2018).Nigeria has over time been consistently ranked low in the fight against corruption. Thus, the expectations from political office holders can only be measured based on consistency of service delivery (Ibeogu and Nkwede, 2016).

\subsection{Theoretical Exposition}

This study used the system theory and the structural functionalism theory for its analysis. The system theory was first espoused by David Easton in 1953. The theory captures the relationship between the people and the policy makers and how they make or reach their decisions. In the view of Saheb (2017), he notes that the system theory has been able to standardize sets of concepts and categories that have the advantage of been logically inconclusive.David Easton was of the opinion that the essence of politics is to understand how authorities arrive at their decision and these decisions are executed in the society. The operations of the institutions such as government, political parties, interest groups or non-governmental associations and the roles they play can be examined and also the they play in decision making, their propaganda and attitudes towards the people's needs can be examined (Izuogu, 2014). 
System theory analyses expectations of political office holders in a way that it expects the systems involved in good governance to work together. These institutions play vital role in ensuring good governance (Easton, 1951). System theory provides for different systems which work interdependently for the smooth running of the state. These systems may include; the people, decision makers, non-governmental system, mass media, pressure group/interest groups etc. expectations refer to what the people expect the government to do and in order to meet up with these expectations, government needs to formulate public policies. In other to solve its complexity, it requires the participation of the different stakeholder in the political community (UPSC, 2007). The participation and interaction of the different institutions can be explained using David Easton's diagram of system theory

\section{Environment Environment}

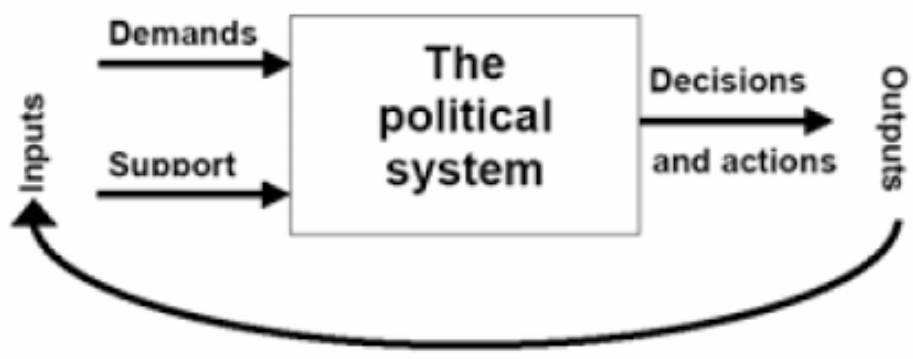

Environment

David Easton (1965): A System Analysis of Political Life

From the above, it can be deciphered that the inputs encompass both demand and supply which refers to the agitations made by the people to the government. It encompasses the expectations of the people and these expectations are channeled to the government (political system). These agitations are made known to the government through seminars, town meetings, demonstrations, strikes, boycotts, mass media and social media in recent times. The political system refers to the decision making arena where political office holders deliberate on issues put forward by the people so as to reach a laudable conclusion that would appease the people. These decisions are made or enforced and it goes back to the people as feedback majorly through the mass media (output). In a way, the people react to these decisions either positivity or negatively depending on how favorably the decision is. This process is a continuous one. It is also important to note from the above diagram that people's needs are endless and to satisfy them pose as a serious challenge. People will always clamor for their needs to be met by the government. The environment refers to the political atmosphere. Systems theory enables us to understand the political system as a place where the values of a society are allocated (Pooja, 2018).System analysis enables us to also understand the interaction between the government and the people. It explains the relationship between the systems involved in policy making process.

The other theory, structural functionalism was propounded by Gabriel Almond in 1960's. This theory is very popular in the social sciences field. This theory seeks to analyze and identify the structures which make up the political science and how they interact with one another (Saheb, 2018). According to Smith (1966), there are four approaches to the study of political systems which includes process, content, function, and form. These components help to provide insight into the functions of a political system and how it relates with other components in the society. According to Gabriel Almond, all political system performs functions in order to stay relevant. In Nigeria, there exist different structures such as executive, legislative, judiciary; non-governmental organizations, pressure groups, political office holders and the people, and each of these systems have functions that they are supposed to play. But often times, political officers are very weak in carrying out their functions (Lawal and Dare, 2012). The inability of these structures to perform their functions affects good governance in the country (Pooja, 2018). We can therefore say that the country is becoming increasingly ungovernable as a result of absence of coordination of the system. 


\section{Presentation of Results and Analysis}

Table 1. Distribution of respondents based on length of stay in the local government area

\begin{tabular}{llll}
\hline Years of Stay & Frequency & Valid Percent & Cumulative Percent \\
\hline Less Than 11 years & 20 & 13.3 & 13.3 \\
$11-20 y r s$ & 31 & 20.7 & 34.0 \\
$21-30$ yrs & 37 & 24.7 & 58.7 \\
$31-40$ yrs & 18 & 12.0 & 70.7 \\
$41-50$ yrs & 30 & 20.0 & 90.7 \\
51 yrs and Above & 14 & 9.3 & 100.0 \\
\hline Total & 150 & 100.0 & \\
\hline
\end{tabular}

Source: Fieldwork, February, 2019

Table 1 above shows the frequency distribution of respondents based on their length of stay at their various local government of residence. It could be seen that $20(13.3 \%)$ of the respondents has lived for less than 11 years at their local government of residence, $31(20.7 \%)$ has stayed for close to 11 to 20 years, $37(24.7 \%)$ has stayedbetween 21 and 30 years, 18(12.0\%) has spent up to 31 and 40 years, 30(20.0\%) of the respondents has stayedup to 41 and 50 years, while respondents that has spent 51 years and above in their local government areas is 14 representing $9.3 \%$ of the total respondents sampled for this study. It is therefore implied that majority of the respondents has stayed at their local governments of residence between 21 and 30 years.

Table 2. Distribution of respondents based on gender

\begin{tabular}{llll}
\hline Age Group & Frequency & Valid Percent & Cumulative Percent \\
\hline Male & 90 & 60.0 & 60.0 \\
Female & 60 & 40.0 & 100.0 \\
\hline Total & 150 & 100.0 & \\
\hline
\end{tabular}

Source: Fieldwork, February, 2019

Table 2 above revealed that $90(60.0 \%)$ of the respondents are male while $60(40.0 \%)$ of the respondents are female. This however showed that the majority of the respondents for this study are male. 
Table 3. Respondents' views on their expectations from political office holders

\begin{tabular}{|c|c|c|c|c|c|c|c|}
\hline $\mathbf{S} / \mathbf{N}$ & Variables & SA (\%) & $A(\%)$ & $\begin{array}{l}\mathrm{U} \\
(\%)\end{array}$ & SD (\%) & D (\%) & Total \\
\hline A & Food & $28(18.7)$ & $9(6.0)$ & $4(2.7)$ & $84(55.9)$ & $25(16.7)$ & $150(100.0)$ \\
\hline B & Clothing & $32(21.3)$ & $4(2.7)$ & $0(0.0)$ & $96(64.0)$ & $18(12.0)$ & $150(100.0)$ \\
\hline $\mathrm{C}$ & Shelter & $36(24.0)$ & $28(18.7)$ & $9(6.0)$ & $54(36.0)$ & $32(21.3)$ & $150(100.0)$ \\
\hline $\mathrm{D}$ & Employment & $110(73.3)$ & $36(24.0)$ & $0(0.0)$ & $4(2.7)$ & $0(0.0)$ & $150(100.0)$ \\
\hline $\mathrm{E}$ & Social Infrastructure & $116(77.3)$ & $25(16.7)$ & $0(0.0)$ & $9(6.0)$ & $0(0.0)$ & $150(100.0)$ \\
\hline $\mathrm{F}$ & Social Services & $114(76.0)$ & $32(21.3)$ & $0(0.0)$ & $4(2.7)$ & $0(0.0)$ & $150(100.0)$ \\
\hline G & Economic Development & $150(100.0)$ & $0(0.0)$ & $0(0.0)$ & $0(0.0)$ & $0(0.0)$ & $150(100.0)$ \\
\hline $\mathrm{H}$ & Medical Facilities & $150(100.0)$ & $0(0.0)$ & $0(0.0)$ & $0(0.0)$ & $0(0.0)$ & $150(100.0)$ \\
\hline I & Agriculture & $80(53.3)$ & $36(24.0)$ & $9(6.0)$ & $25(16.7)$ & $4(2.7)$ & $150(100.0)$ \\
\hline $\mathrm{J}$. & Education & $107(71.3)$ & $25(16.7)$ & $0(0.0)$ & $14(9.3)$ & $4(2.7)$ & $150(100.0)$ \\
\hline K & Industrial development & $88(58.7)$ & $54(36.0)$ & $8(5.3)$ & $8(5.3)$ & $0(0.0)$ & $150(100.0)$ \\
\hline $\mathrm{L}$ & Security of life and properties & $150(100.0)$ & $0(0.0)$ & $0(0.0)$ & $0(0.0)$ & $0(0.0)$ & $150(100.0)$ \\
\hline 1. & $\begin{array}{l}\text { Political office holders are aware of } \\
\text { their expectations }\end{array}$ & $72(48.0)$ & $46(30.7)$ & $8(5.3)$ & $24(16.0)$ & $0(0.0)$ & $150(100.0)$ \\
\hline $\begin{array}{l}2 . \\
\text { A }\end{array}$ & $\begin{array}{l}\text { The expectations are communicated } \\
\text { to political office holders through: } \\
\text { Social media }\end{array}$ & $28(18.7)$ & $9(6.0)$ & $4(2.7)$ & $84(55.9)$ & $25(16.7)$ & $150(100.0)$ \\
\hline B & $\begin{array}{l}\text { Community development } \\
\text { association }\end{array}$ & $32(21.3)$ & $4(2.7)$ & $0(0.0)$ & $96(64.0)$ & $18(12.0)$ & $150(100.0)$ \\
\hline $\mathrm{C}$ & Mass media & $36(24.0)$ & $28(18.7)$ & $9(6.0)$ & $54(36.0)$ & $32(21.3)$ & $150(100.0)$ \\
\hline $\mathrm{D}$ & House of Representatives & $110(73.3)$ & $36(24.0)$ & $0(0.0)$ & $4(2.7)$ & $0(0.0)$ & $150(100.0)$ \\
\hline $\mathrm{E}$ & Political campaign & $116(77.3)$ & $25(16.7)$ & $0(0.0)$ & $9(6.0)$ & $0(0.0)$ & $150(100.0)$ \\
\hline $\mathrm{F}$ & Direct contact with & $114(76.0)$ & $32(21.3)$ & $0(0.0)$ & $4(2.7)$ & $0(0.0)$ & $150(100.0)$ \\
\hline
\end{tabular}

Source: Fieldwork, February, 2019

Table 3 above shows percentage distribution of respondents based on the opinion of the respondents on their expectations from political office holders. According to item A of the above table, it revealed that $18.7 \%$ of the respondents strongly agreed that political office holders are supposed to provide food for them, $6.0 \%$ Agreed, $2.7 \%$ were undecided while $55.9 \%$ strongly disagreed and $16.7 \%$ disagreed with the assertion. The data in item B above showed that $21.3 \%$ strongly agreed that political office holders should provide clothing for them, $2.7 \%$ agreed, while $64.0 \%$ strongly disagreed and $12.0 \%$ disagreed. The data in item $\mathrm{C}$ above showed that $24.0 \%$ agreed that political office holders should also provide shelter for them, $18.7 \%$ agreed, $6.0 \%$ were undecided while $36.0 \%$ strongly disagreed and $21.3 \%$ disagreed. The data in item D above showed that $73.3 \%$ strongly agreed that political office holders should provide them employment, $24.0 \%$ agreed while $2.7 \%$ of the respondents strongly disagreed with the assertion. Under item E, 77.3\% of the respondents strongly agreed that the political office holders should provide social infrastructure for the citizens, $16.7 \%$ agreed, while $6.0 \%$ strongly disagreed. The data in item $\mathrm{F}$ above insinuates that $76.3 \%$ of the respondents strongly agreed with the assertion that political office holders should provide social services, $21.3 \%$ agreed, while $2.7 \%$ of the respondents strongly disagreed with the assertion. In item $\mathrm{G}$ of the above table, $100.0 \%$ of the respondents agreed that the political office holders should provide economic development for the citizens. In item $\mathrm{H}$ of the above table, $100.0 \%$ of the respondents agreed that the political office holders should provide medical facilities for the citizens. The data in item I above posits that $53.3 \%$ of the respondents strongly agreed with the assertion that political office holders should provide agricultural services, $24.0 \%$ agreed, $6.0 \%$ were undecided, while $16.7 \%$ of the respondents strongly disagreed and $2.7 \%$ disagreed with the assertion. In item $\mathrm{J}$ of the above table, $71.3 \%$ 
of the respondents strongly agreed that the political office holders should provide quality education for the citizens, $16.7 \%$ agreed, while $11.3 \%$ strongly disagree and $2.7 \%$ disagree with the assertion. In item $\mathrm{K}$ of the above table, $58.7 \%$ of the respondents strongly agreed that the political office holders should provide industrial development for the citizens, $36.0 \%$ agreed, $5.3 \%$ were undecided, while $5.3 \%$ strongly disagree with the assertion. In item I of the above table, $100.0 \%$ of the respondents agreed that the political office holders should provide security for lives and properties of the citizens.

Also, Table 3 above showed percentage distribution of respondents based on the opinions of the respondents on whether political office holders are aware of the expectations from them by the citizens. The item 1 in the table revealed that $48.0 \%$ of the respondents strongly agreed that political office holders are aware of expectations of them by the citizens, $30.7 \%$ agreed, $5.3 \%$ were undecided while $16.0 \%$ disagreed with the assertion. Table 3 above also showed percentage distribution of respondents based on the opinion of the respondents on means of communicating the expectations to the political office holders. According to Item 2 of the above table, it revealed that $18.7 \%$ of the respondents strongly agreed that they communicate their expectations through the mass media, $6.0 \%$ agreed, $2.7 \%$ were undecided, $55.9 \%$ strongly disagreed while $16.7 \%$ disagreed. $21.3 \%$ strongly agreed that they communicate it through their various community development association $2.7 \%$ agreed, $64.0 \%$ strongly disagreed while $12.0 \%$ disagreed. Also, $24.0 \%$ strongly agreed that they communicate it through the media, $18.7 \%$ agreed, $6.0 \%$ were undecided, $36.0 \%$ strongly disagreed while $21.3 \%$ disagreed. $73.3 \%$ strongly agreed that they communicate it through the House of Representative, $24.0 \%$ agreed, while $2.7 \%$ disagreed. $77.3 \%$ of the respondents strongly agreed that they communicate their expectations through political campaign, $16.7 \%$ agreed, while $6.0 \%$ of the respondents disagreed. $76.0 \%$ of the respondents strongly agreed that they communicate their expectations to the political office holders through direct contact with political office holders, $21.3 \%$ agreed, while $2.7 \%$ disagreed. So, it can be deduced that majority of the respondents communicates their expectations to the political office holder through social media.

Table 4. Respondents' views on how effective political office holders have met their expectations

\begin{tabular}{llllllll}
\hline S/N & & SA & A & U & SD & D & Total \\
\hline A & Food & $23(15.3)$ & $95(63.3)$ & - & $27(18.0)$ & $5(3.3)$ & $150(100.0)$ \\
B & Clothing & $28(18.0)$ & $87(58.0)$ & - & $30(20.0)$ & $5(3.3)$ & $150(100.0)$ \\
C & Shelter & $19(12.0)$ & $99(66.0)$ & - & $27(18.0)$ & $5(3.3)$ & $150(100.0)$ \\
D & Employment & $28(18.7)$ & $75(50.0)$ & - & $47(3.3)$ & - & $150(100.0)$ \\
E & Social infrastructure & $26(17.3)$ & $61(40.7)$ & - & $63(42.0)$ & - & $150(100.0)$ \\
F & Social services & $26(17.3)$ & $66(44.0)$ & - & $58(38.7)$ & - & $150(100.0)$ \\
G & Economic development & $12(8.0)$ & $80(53.3)$ & - & $58(38.7)$ & - & $150(100.0)$ \\
H & Medical facilities & $38(25.3)$ & $64(42.7)$ & - & $48(32.0)$ & - & $150(100.0)$ \\
I & Agriculture & $21(14.0)$ & $68(45.3)$ & - & $56(37.3)$ & $5(3.3)$ & $150(100.0)$ \\
J & Education & $35(23.3)$ & $61(40.7)$ & - & $39(26.0)$ & $15(10.0)$ & $150(100.0)$ \\
K & Industrial development & $45(30.0)$ & $49(32.7)$ & - & $51(34.0)$ & $5(3.3)$ & $150(100.0)$ \\
L & Security of life and properties & $30(20.0)$ & $38(25.3)$ & - & $72(48.0)$ & $10(6.7)$ & $150(100.0)$ \\
\hline
\end{tabular}

Fieldwork: February, 2019

Table 4 above showed percentage distribution of respondents on how effective political office holders have met the expectations of the citizens. Item A of the above table revealed that $15.3 \%$ of the respondents strongly disagreed that political office holders effectively meet the provision of foods, $63.3 \%$ disagreed, $18.0 \%$ agreed while $3.3 \%$ strongly agreed. The item B of the table showed that $18.7 \%$ of the respondents strongly disagreed that political office holders meet the provision of clothing, $58.0 \%$ disagreed, $20.0 \%$ agreed while $3.3 \%$ strongly agreed. Item $\mathrm{C}$ revealed that $12.7 \%$ of the respondents strongly disagreed that political office holders meet the provision of shelter for the citizens, $66.0 \%$ disagreed, $18.0 \%$ agreed while $3.3 \%$ strongly agreed. Item $\mathrm{D}$ revealed that $18.7 \%$ of the respondents strongly disagreed that political office holders meet the provision of employment for the citizens, $50.0 \%$ disagreed, while $3.3 \%$ strongly agreed. Also, Item E indicated that $17.3 \%$ of the respondents strongly disagreed that political office holders meet the provision of social infrastructure for the 
citizens, $40.7 \%$ disagreed, while $42.0 \%$ agreed. Item $\mathrm{F}$ on table 4 above indicated that $17.3 \%$ of the respondents strongly agreed that political office holders provide social services for the citizens, $44.0 \%$ disagreed, while $38.7 \%$ agreed. Data in Item $\mathrm{G}$ revealed that $8.0 \%$ of the respondents strongly agreed that political office holders meet the provision of state economic development, $53.3 \%$ agreed, while $38.7 \%$ disagreed. Item $\mathrm{H}$ indicated that $25.3 \%$ of the respondents strongly disagreed that political office holders provide medical facilities of the state, $42.7 \%$ disagreed, while $32.0 \%$ agreed. Also, Item I revealed that $14.0 \%$ of the respondents strongly disagreed that political office holders provide for agricultural needs of the citizens, $45.3 \%$ disagreed, $37.3 \%$ agreed while $3.3 \%$ strongly agreed. The data in item $\mathrm{J}$ above showed that $23.3 \%$ of the respondents strongly disagreed that political office holders provide for quality education, $40.7 \%$ disagreed, $26.0 \%$ agreed while $10.0 \%$ strongly agreed. Item $\mathrm{K}$ indicated that $30.0 \%$ of the respondents strongly disagreed that political office holders provide for industrial development needs of the citizens, $32.7 \%$ disagreed, $34.0 \%$ agreed while $3.3 \%$ strongly agreed. Also, Item L revealed that $20.0 \%$ of the respondents strongly disagreed that political office holders provide for security of life and properties, $25.3 \%$ disagreed, $48.0 \%$ agreed while $6.7 \%$ strongly agreed.

Table 5. Respondents' views on the factors that prevent political office holders from meeting their expectations

\begin{tabular}{|c|c|c|c|c|c|c|c|}
\hline $\mathbf{S} / \mathbf{N}$ & Variables & SA & $\mathbf{A}$ & $\mathbf{U}$ & SD & D & Total \\
\hline A & Lack of funds & $116(77.3)$ & $25(16.7)$ & $0(0.0)$ & $9(6.0)$ & $0(0.0)$ & $150(100.0)$ \\
\hline B. & $\begin{array}{l}\text { Corrupt practices of political office } \\
\text { holders }\end{array}$ & $114(76.0)$ & $32(21.3)$ & $0(0.0)$ & $4(2.7)$ & $0(0.0)$ & $150(100.0)$ \\
\hline C. & Influence of political godfathers & $150(100.0)$ & $0(0.0)$ & $0(0.0)$ & $0(0.0)$ & $0(0.0)$ & $150(100.0)$ \\
\hline D. & Lack of manpower & $150(100.0)$ & $0(0.0)$ & $0(0.0)$ & $0(0.0)$ & $0(0.0)$ & $150(100.0)$ \\
\hline E. & Lack of support from citizens & $80(53.3)$ & $36(24.0)$ & $9(6.0)$ & $25(16.7)$ & $4(2.7)$ & $150(100.0)$ \\
\hline F. & $\begin{array}{l}\text { Inadequate experience/ exposure of } \\
\text { political office holders }\end{array}$ & 107(71.3) & $25(16.7)$ & $0(0.0)$ & $14(9.3)$ & $4(2.7)$ & $150(100.0)$ \\
\hline G. & $\begin{array}{l}\text { Lack of channel for communicating } \\
\text { public expectations to political office } \\
\text { holders }\end{array}$ & $88(58.7)$ & $54(36.0)$ & $8(5.3)$ & $8(5.3)$ & $0(0.0)$ & $150(100.0)$ \\
\hline
\end{tabular}

Fieldwork: February, 2019

Table 5 above showed percentage distribution of respondents' views of what they considered as factors that prevents political office holders from meeting their expectations to the citizens. In item $\mathrm{H}$ of the above table, $77.3 \%$ of the respondents strongly agreed that lack of funds prevents political office holders from meeting citizen expectations, $16.7 \%$ agreed, while $6.0 \%$ strongly disagreed. The data in item I above revealed that $76.3 \%$ of the respondents strongly agreed with the assertion that corrupt practices of political office holders prevent them from meeting their expectations, $21.3 \%$ agreed, while $2.7 \%$ strongly disagreed. Item $\mathrm{J}$ of the above table revealed that $100.0 \%$ of the respondents agreed that the influence of political godfathers prevent political office holders from meeting their expectations. In item $\mathrm{K}$ of the above table, $100.0 \%$ of the respondents agreed that the lack of manpower prevent political office holders from meeting their expectations. The data in item $\mathrm{L}$ above indicated that $53.3 \%$ of the respondents strongly agreed that lack of support from citizens prevents political office holders from meeting their expectations, $24.0 \%$ agreed, $6.0 \%$ were undecided, while $16.7 \%$ of the respondents strongly disagreed and $2.7 \%$ disagreed with the assertion. In item $\mathrm{M}$ of the above table, $71.3 \%$ of the respondents strongly agreed that inadequate experience/exposure of political office holders prevents them from meeting their expectations, $16.7 \%$ agreed, while $11.3 \%$ strongly disagree and $2.7 \%$ disagreed. In item $\mathrm{N}$ of the above table, $58.7 \%$ of the respondents strongly agreed that lack of channel for communicating public expectations to political office holders prevents them from meeting their expectations, 36.0\% agreed, 5.3\% were undecided, while 5.3\% strongly disagreed. 
Table 6. Respondents' views on the factors that aid political office holders from meeting their expectations

\begin{tabular}{|c|c|c|c|c|c|c|c|}
\hline $\mathbf{S} / \mathbf{N}$ & & SA & $\mathbf{A}$ & $\mathbf{U}$ & SD & D & Total \\
\hline A & $\begin{array}{l}\text { Proper communication of } \\
\text { expectations to political office } \\
\text { holders }\end{array}$ & $28(18.7)$ & $9(6.0)$ & $4(2.7)$ & $84(55.9)$ & $25(16.7)$ & $00.0)$ \\
\hline B & $\begin{array}{l}\text { Accurate representation of the } \\
\text { electorate }\end{array}$ & $32(21.3)$ & $4(2.7)$ & $0(0.0)$ & $96(64.0)$ & $18(12.0)$ & $150(100.0)$ \\
\hline $\mathrm{C}$ & Availability of funds & $36(24.0)$ & $28(18.7)$ & $9(6.0)$ & $54(36.0)$ & $32(21.3)$ & $150(100.0)$ \\
\hline $\mathrm{D}$ & Adequate and skilled manpower & $110(73.3)$ & $36(24.0)$ & $0(0.0)$ & $4(2.7)$ & $0(0.0)$ & $150(100.0)$ \\
\hline $\mathrm{E}$ & Citizen support & $26(17.3)$ & $61(40.7)$ & $0(0.0)$ & $63(42.0)$ & - & $150(100.0)$ \\
\hline $\mathrm{F}$ & Integrity of political office holders & $26(17.3)$ & $66(44.0)$ & & $58(38.7)$ & - & $150(100.0)$ \\
\hline G & $\begin{array}{l}\text { Experience/ exposure of political } \\
\text { office holder }\end{array}$ & $12(8.0)$ & $80(53.3)$ & & $58(38.7)$ & - & $150(100.0)$ \\
\hline
\end{tabular}

Fieldwork: February, 2019

Table 6 above shows percentage distribution of respondents' views on what they considered as factors that aid political office holders to meet the expectations of the citizens. Item A of the table revealed that $18.7 \%$ of the respondents strongly agreed that proper communication of expectations to political office holders aids provision of expectations by political office holders for the citizens, $6.0 \%$ agreed, $2.7 \%$ were undecided while $55.9 \%$ strongly disagreed and $16.7 \%$ disagreed. The data in item B above showed that $21.3 \%$ of the respondents strongly agreed that accurate representation by the electorate makes expectations of the citizens to be quickly met by the political office holders, $2.7 \%$ agreed, while $64.0 \%$ strongly disagreed and $12.0 \%$ disagreed. The data in item $\mathrm{C}$ above showed that $24.0 \%$ of the respondents strongly agreed that availability of funds enables expectations of the citizens to be easily met, $18.7 \%$ agreed, $6.0 \%$ were undecided while $36.0 \%$ strongly disagreed and $21.3 \%$ disagreed. The data in item $\mathrm{D}$ above showed that $73.3 \%$ of the respondents strongly agreed that adequate and skilled manpower aids meeting of the expectations of citizens by political office holders, $24.0 \%$ agreed while $2.7 \%$ of the respondents strongly disagreed. Also, Item E posits that $17.3 \%$ of the respondents strongly disagreed with the assertion that citizen support aids meeting of their expectations by political office holders, $40.7 \%$ disagreed, while $42.0 \%$ agreed. Item $\mathrm{F}$ showed that $17.3 \%$ of the respondents strongly agreed that the integrity of political office holders assists in meeting the expectations of the citizens by political office holders, $44.0 \%$ disagreed, while $38.7 \%$ agreed. Data in Item G above showed that $8.0 \%$ of the respondents strongly agreed with the assertion that the experience and/or exposure of political office holder aids the meeting of citizens expectation, $53.3 \%$ agreed, while $38.7 \%$ disagreed.

Table 7. Frequency distribution of respondents views on impacts of public expectation on good governance

\begin{tabular}{llclllll}
\hline S/N & Variables & SA (\%) & $\begin{array}{l}\text { A } \\
(\%)\end{array}$ & $\begin{array}{l}\text { U } \\
(\%)\end{array}$ & & SD (\%) & $\begin{array}{l}\text { D } \\
\text { (\%) }\end{array}$ \\
\hline 1 & $\begin{array}{l}\text { Do public expectations have impacts on good } \\
\text { governance? }\end{array}$ & $112(74.7 \%)$ & - & - & $38(25.3)$ & - & $150(100.0)$ \\
& & & & & & \\
\hline
\end{tabular}

Source: Fieldwork, February, 2019

Table 7 above shows percentage distribution of respondents on the impacts of public expectations on good governance. According to item 1 of the above table, it revealed that $74.7 \%$ of the respondents strongly agreed that public expectations have impacts on good governance, while $25.3 \%$ strongly disagreed with the assertion. 
Table 8. Frequency distribution of respondents views on the type of influence public expectations have on good governance

\begin{tabular}{lllll}
\hline $\mathrm{S} / \mathrm{N}$ & Variables & Positive (\%) & Negative (\%) & Total \\
\hline 1 & If yes, what type of influence? & $112(74.7 \%)$ & $38(25.3)$ & $150(100.0)$ \\
\hline
\end{tabular}

Source: Fieldwork, February, 2019

Table 8 above shows percentage distribution of respondents on the type of influence public expectations have on good governance. According to the above table, it revealed that $74.7 \%$ of the respondents agreed that public expectations have positive impacts on good governance, while $25.3 \%$ disagreed with the assertion.

\section{Discussion}

This study assessed the opinion of citizens from 33 local governments in Oyo state on their expectations from political office holders on good governance. The data gathered indicate that there are more male participants in the survey than female participants, thus more men were involved in the activities of politics than women. This finding tallies with the submission of Getu (2001) who notes that women are still been discriminated in Nigerian politics as a result of the people's culture and religion. Also, statistics on the age distribution of the respondents show that most of the respondents are young adults. The finding on age distribution affirms the submission of (Anyadike and Emeh, 2014) that partisan politics get reduced from the age of 60 years.

The study also revealed that the electorates expects political office holders to provide some basic amenities like food, clothing, shelter, employment, social infrastructure, economic development, medical facilities, agriculture, education and so on. More so, many of the respondents believed that the political office holders are aware of their expectations and that they communicate their expectations majorly through social media and mass media. The finding reinforces the importance of the mass media to politics, which Pierre and Ismail (1991) note is capable of influencing people at the corridor of power. This accounts for why Zimako (2009) posits that responsible government all over the world now place utmost priority on information on social media and mass media to gauge the feelings of members of the public. It also corroborates the submission of Oaikhena and Osawe (2012) who note that ability to do well in government is largely influenced by the extent to which a policy maker is able to meet the demands raised on social media platforms. However, this study is of the view that political office holders have not effectively met their expectations on food, clothing, shelter, employment, social infrastructure, social service, economic development, medical facilities, agriculture, education, industrial development and security of life and properties. We can say that most political actors are aware of expectations expected of them but could not meet them as a result of greed, huge sum of money spent on electioneering campaigns, corruption and influence of godfathers.

The study revealed that proper communication with political office holders, accurate representation, availability of funds, adequate and skilled manpower, integrity of political office holders and their experience are factors that aid political office holders in meeting the expectations of the citizens, while lack of funds, corrupt practices of political office holders, influence of political godfathers, lack of manpower and support from citizens and poor communication of expectations to political office holders are hindrances that prevent political office holders from meeting public expectations. Finally, the study revealed that public expectations have positive impacts on good governance but political office holders in Oyo state have a lot of work to do in order to meet the expectations of their teeming populace.

\section{Conclusion}

The process of meeting the expectations of members of the public by political office holders requires adequate priority. Although, expectations are not often feasible because of the insatiable nature of human beings, yet, political actors should strive to provide the public with basic needs in order to bring about positive changes in their standard of living. Governing process would be meaningful when political office holders genuinely attend to the needs of members of the public. When political office holders take the expectations of the people into cognizance, the polity becomes peaceful, such that the people are not at loggerheads with their political representatives.

\section{Recommendations}

The following recommendations can help political office holders in meeting up with the expectations of the people in order to ensure a smooth governing process. One, government should ensure that development is 
carried out in all local governments, in a way that no local government area of the state is given more attention at the expense of others. There should be equal distribution of development activities across the state.

In addition, people's expectations should be taken into consideration as it is the yardstick by which the performances of public office holders are measured. Local government should be given autonomy as stipulated in the constitution so that they can judiciously and independently mobilize resources in their disposal to provide for the needs of the people.

It is important that public office holders embrace transparency and accountability in order to ensure a democratic governing process. Political office holders should ensure that whatever actions and plans they tend to pursue, majority of the people are carried along. To effectively do this, public officers should be guided with rule of law, protection of human rights and existence of an honest government.

Also, qualified and capable individuals with integrity should be elected to see to the state's development as they are enlightened enough to know what is best for the state. They should also appoint professionals who are well informed in the governing process.

The government should diversify its source of income. It can invest in agricultural sector to boost the economy of the state and even create job opportunities for the unemployed youths. If this is done criminalities would reduce. Government should attract investors from other states and foreign countries to raise the standard of living of residents.

Political office holders should ensure that they take public opinion into cognizance. This would help to address public agitations. Political office holders should also avoid use of public properties for private purposes. The Economic and Financial Crimes Commission needs to use its power more diligently in this regards. It needs to be apolitical.

\section{References}

Achumba, I., Ighomereho, O., \& Akpor-Robaro, M. (2013). Security Challenges in Nigeria and the Implication for Business Activities and Sustainable Development. Journal of Economics and Sustainable Development, 4(2), 79-99. https://doi.org/10.9774/GLEAF.8757.2013.se.00008

Adamolekun, L. (2002). Governance Context and Reorientation of Government.In L.Adamolekun (Eds.), Public Administration in Africa, Man Issues and Selected Country Studies. Ibadan, Spectrum Books Limited.

Anyadike, N., \& Emeh, E. (2014).Effective Leadership for Good Governance in Nigeria; Addressing the Interface. Journal of Humanities and Social Science, 19(1), 69-74. https://doi.org/10.9790/0837-191106974

Bada, G. (2018). These are the $21^{\text {st }}$ most corrupt countries in Africa. Business Insider by Pulse. Retrieved from https:www.pulse.ng/bi/politics/these-are-the-21 ${ }^{\text {st }}$-most-corrupt-countries-in-african-id8021690.html

Getu, T. (2001). Governance and Development in Africa, in Challenges and Prospects for Sustainable development in African.UNDP, New York.

Ibeogu, A., \& Nkwede, V. (2016). Transparency, Good Governance, Ethical Conduct, And Accountability As An Instrument To Guarantee Financial Corrupt Free Public Service: The Local Government Experience In Ebonyi State, 2007-2015. IOSR Journal of Humanities And Social Sciences, 21(8), 66-71. https://doi.org/10.9790/0837-2108036671

Izuogu, S. A. (2014). A Critique of Functionalism as a Theory of the Contemporary Nigerian Social System. South South Journal of Culture and Development, 16(2), 1-18.

Lamidi, O. and Adeyeye, M. (2013). An Assessment of Leadership Role of Political Office Holders In The $21^{\text {st }}$ Century At The Nigerian Local Government Level: A Theoretical Perspective. Journals of Public Administration And Policy Research, 5(4), 102-108. https://doi.org/10.5897/JPAPR2013.0245

Lawal, T., \& Dare, O. (2012). Leadership Debacle: The Bane of Good Governance in Nigeria. Afro Asian Journal of Social Sciences, 3(3.3), 2229-5313.

Michael, J. (2004). Good governance: Rule of law, Transparency and accountability. Colgate University New $\begin{array}{lllll}\text { York. } & \text { Retrieved } & \text { December } & \text { 2018, } & \text { from }\end{array}$ http://unpan1.un.org/intradoc/groups/public/documents/un/unpan010193

Oaikhena, I. M., \& Osawe, C. (2012). Building Strong Democratic Institutions: A Panacea to Good Governance and Policy Implementation in Nigeria. Kogi Journal of Politics Kogi State University, Anyigba, Nigeria.

Onichakwe, C. (2016). The Role of Good Governance and Development Administration in National 
Development. International Journal of Development and Management Review, 11, 176-186.

Pierre, L., \& Ismail, S. (1991). Governance and the External Factor. World Bank Economic Review, 303-320. https://doi.org/10.1093/wber/5.suppl_1.303

Pooja, E. (2018). System Theory According to David Easton. RetrievedApril7, 2019, fromhttps://politicalsciencenotes.com

Premuim Times. (2012). Ibori Gets 13 Years In Jail. Premium Times. Retrieved October 18, 2018from http://www.premiumtiesng.com/news/4682-Ibori-gets-13years-in-jail.html

Sahara Reporters. (2018). Breaking: FG Releases Names of Looters'. Sahara Reporters.Retrieved April 18, 2019, from https://saharareporters.com/2018/03/30/breakin-fg-releases-names-\%E2\%98\%looters $\% \mathrm{E} 2 \% 80 \% 99 \%$

Saheb, D. (2017). Essay on Structural Functional Approach to the Study Political science.Navigation.Retrieved from

www.shareyouressays.com/knowledge/essay-on-the-structural-functionalapproach-to-study-political-scienc e/112573

Saheb, D. (2018). What is the Significance of Easton's System Theory of Political Science? Retrieved March 25, 2019 , from www.shareyouressays.com/knowledge/what-is-the-significance-of-eastons-systems-theory-of-political-scie nce/1112576

United Nations. (2018).What is Good Governance? United Nations Economic and Social Commission for Asia and the Pacific.

UPSC Practice. (2007). Gabriel almond's structural functional approach. Retrieved May 6, 2019, from upscpractice.blogspot.com/2017/101/structuralfunctional-approach-gabriel-5.html?m=1

\section{Copyrights}

Copyright for this article is retained by the author(s), with first publication rights granted to the journal.

This is an open-access article distributed under the terms and conditions of the Creative Commons Attribution license (http://creativecommons.org/licenses/by/4.0/). 